\title{
The Effect of Using Smartphone Based Learning Media to Improve Students' Critical Thinking Skills During Covid-19 Pandemic
}

\author{
Aniesatus Sa'diyah ${ }^{1,{ }^{*}}$ Insih Wilujeng ${ }^{2}$, Nuraini Nadhiroh ${ }^{1}$ \\ ${ }^{1}$ Master of Physics Education Magister Program, Faculty of Mathematics and Natural Sciences, Universitas \\ Negeri Yogyakarta, Indonesia \\ ${ }^{2}$ Department of Science Education, Faculty of Mathematics and Natural Sciences, Universitas Negeri \\ Yogyakarta, Indonesia \\ *Corresponding author. Email: aniesatussadiyah.2018@student.uny.ac.id
}

\begin{abstract}
This research aims to determine the effect of smartphone-based learning media in the students' critical thinking skills. This research was a quasi-experimental with only Posttest Control Group Design. The sample of this reasearch were students of class XI MIPA 1 and XI MIPA 2 at SMAN 1 Ngaglik in the academic year 2019/2020 who were taken by simple random sampling. Data collection instrument was developed based on indicators critical thinking skills namely understanding, application, analysis, evaluation, and generalize. The analysis of this research used descriptive analysis and independent $t$ test. The results of $t$ test analysis showed critical thinking skills of experimental class were significantly higher than the control class. It means that the use of smartphone-based learning media has an effect in improving the critical thinking skills of students.
\end{abstract}

Keywords: Learning media, Smartphone, Critical thinking skills

\section{INTRODUCTION}

Technological developments can be used as an innovative and creative learning medium for teachers and students [1]. The convenience offered by technology can support teacher and student communication interactively during the Covid-19 pandemic. Students can access the material more easily. Technology can also help students in the learning process [2]. Teaching materials that are mobile can be used as a substitute for teaching materials such as books, textbooks, other printed sources. This learning material is packaged in electronic form and has advantages in the form of images, videos, and animation [3]. Although it can facilitate learning, the existing technology has not been fully utilized. Its use is limited to social nets [4].

Teaching materials that are mobile or often referred to as mobile learning can help students arrange experiments, understand procedures, think about the influence of variables, communicate and present the results obtained. One example of mobile learning that can be used is a smartphone. The development of smartphone devices is getting higher and the prices are relatively cheap are factors that support the increase in smartphone use. In Indonesia, the growth of smartphones reaches $62 \%$ per year and for the Android OS it reaches 50-60\% [5]. This shows that smartphones are very easily accessible to everyone, including educators and students. The use of smartphones makes students understand the subject matter easily. The material presented is not only in the form of writing and images, but can also be in the form of video or experimental animation. This video or experiment animation will make learning run more effectively and students have a pleasant learning experience [6].

Physics is a subject that consists of concepts. Understanding the concept is important in studying physics. The Coronavirus 19 outbreak that hit Indonesia in early March 2020 had a tremendous impact in various aspects of life, especially in the field of education [7]. Education, which is usually held face-to-face in schools, during a pandemic must be carried out from home (study from home). Students also experienced learning difficulties during the pandemic. During the Covid 19 pandemic, students had to study online which needed 
communication tools such as laptops / smartphones that were used to facilitate teacher-student communication. Even though education is constrained by the Covid-19 outbreak, education must continue to run to prepare the quality of Indonesian people in facing the 4.0 industrial revolution.

The challenges of the 21 st century require people to have skills including: (1) ICT and media skills; (2) critical thinking skills; (3) problem solving skills; (4) communication skills; and (5) collaboration skills [8]. One of the skills that need to be taught to students in the face of the globalization era is critical thinking skills [9]. Critical thinking skills are mental processes used to analyze and evaluate information or problems [10]. When we think, at that moment we are forming a concept, a consideration to make a decision.

Critical thinking skills will make it easier for students to make decisions when facing a problem [11]. The use of critical thinking skills is an important component for solving physics problems [12] [13]. Critical thinking skills are logical thinking skills in making decisions based on what they believe. A person is said to think critically if he has the following skills or indicators: (1) understanding; (2) application; (3) analysis; (4) evaluation; and (5) generalize [15].

Critical thinking skills can be taught by innovative learning. In the midst of the Covid-19 pandemic that has hit the world, especially Indonesia, the education system requires educators to be able to use distance learning media[16]. Technological literacy and communication skills are needed in delivering learning material so that it is easily understood by students [17],[18].

According to constructivism theory, critical thinking skills can be developed by accustoming students to solve problems on their own and not only at the end of learning, but problems are also given at the beginning of learning [19]. Critical thinking skills are not suitable if students are passive with learning that is only informative. Informative learning will only make students lazy, do not have strong curiosity, and do not have the ability to communicate the ideas they have [20].

The use of smartphone-based learning media makes it possible to improve students' critical thinking skills. Learning materials can be presented in a more attractive, more interactive way, and students can study anywhere and anytime. The mastery of concepts and critical thinking skills of students who use interactive multimedia on temperature and heat material is higher than students who use conventional learning [21]. Simulation videos and examples of interactive questions in learning are presented in smartphone-based media that make it easier for students to understand abstract physics concepts. Learning with mobile learning media will feel more quality and effective in improving students' ability to draw conclusions from problems [22]. Based on these results, it is necessary to develop and study further learning by utilizing smartphone-based learning media. Next, we will examine the effect of using smartphone-based learning media in improving students' critical thinking skills during the Covid-19 pandemic.

\section{RESEARCH METHOD}

This research was a quasi experimental using Posttest Only Control Group Design. The sample research was students of class XI MIPA SMAN 1 Ngaglik who were taken by simple random sampling. Class XI MIPA 1 as the control class and class XI MIPA 2 as the experimental class. Experimental class used smartphone learning media, while the control class used conventional learning only with Student Worksheets. The analysis of hypothesis in this study was using the independent sample t test to determine the significant differences between the two classes. Table 1 shows the research design used in this research [23].

Table 1. Research design with only posttest control group design

\begin{tabular}{|c|c|c|c|}
\hline Class Type & Pretest & Treatment & Posttest \\
\hline Experiment & -- & $\mathrm{X}$ & $\mathrm{O}_{1}$ \\
Control & -- & -- & $\mathrm{O}_{2}$ \\
\hline
\end{tabular}

The learning media is uploaded in google classroom then students download and install it on their smartphone. The smartphone learning media which used in this learning is learning media oriented to solve problems. Giving this problem is expected that students gain learning experience so that they can find concepts and can foster critical thinking skills. The first problem is given in the "tahukah kamu?" menu which contains the video of Covid 19 virus that is currently hitting the world. From this menu, students are directed to how can humans detect a virus that is very small?

The next menu is the "material" menu. The material menu contains the concept of the microscope, the parts of the microscope and its functions are described in detail so it help students think in real terms. In this menu there is also an animation of light travel in accommodation and without accommodation. This animation help 
students to analyze the image formation that occurs using a microscope with accommodation and without accommodation.

This learning media is also equipped with examples of interactive questions that provide explanations to students in solving calculation problems in a microscope. The question exercise menu can be used by students to practice their ability to evaluate a problem. After evaluating and analyzing, it is hoped that students can draw conclusions about the image formation that occurs in the microscope.To support the results of analyzing, the indicator of critical thinking skill in the each class was analyzed with equations:

Critical Thinking Level $=\frac{\text { Score Obtained }}{\text { Maximum Score }} \times 100 \%$

Table 2. Students' critical thinking skills category

\begin{tabular}{|c|c|}
\hline Persentage (\%) & $\begin{array}{l}\text { Critical Thinking Skill } \\
\text { Categories }\end{array}$ \\
\hline $81.25<X \leq 100$ & Very Good \\
$71.50<X \leq 81.25$ & Good \\
$62.50<X \leq 71.50$ & Moderate \\
$43.75<X \leq 62.50$ & Less \\
$0<X \leq 43.75$ & Very Less \\
\hline
\end{tabular}

The results of the level of critical thinking skills according to the equation above will be interpreted into Table 2. Table 2 shows the categories of students' critical thinking skills [24].

\section{RESULT AND DISCUSSION}

This research aims to determine students' critical thinking skills who get studyng by using smartphone-based learning media compared with students who get conventional learning. The research result in experimental and control classes are presented in Table 3.

Table 3. Comparison of critical thinking skills

\begin{tabular}{|c|c|c|c|c|}
\hline \multirow[t]{2}{*}{$\begin{array}{l}\text { Class } \\
\text { Type }\end{array}$} & \multirow[t]{2}{*}{$\begin{array}{l}\text { Total } \\
\text { Students }\end{array}$} & \multicolumn{3}{|c|}{$\begin{array}{l}\text { Score of Critical Thinking } \\
\text { Skills }\end{array}$} \\
\hline & & Lowest & $\begin{array}{l}\text { Highe } \\
\text { st }\end{array}$ & $\begin{array}{l}\text { Avera } \\
\text { ge }\end{array}$ \\
\hline Experim & 29 & 25 & 100 & 73,93 \\
\hline $\begin{array}{l}\text { ent } \\
\text { Control }\end{array}$ & 32 & 13 & 100 & 66,59 \\
\hline
\end{tabular}

Table 3 shows the average critical thinking skills in experimental class using smartphone learning media are higher than the control class. It means learning using smartphone-based learning media can help students understand learning material independently. Smartphonebased learning media equipped with pictures, videos, and experimental animations can help students understand the subject matter in a concrete and logical manner. Indirectly, the use of smartphone-based learning media guides students to activity and be involved in learning. The involvement of active students in learning is very necessary. it makes the learning objectives can be achieved easily[25].

The significant difference of critical thinking skills in experimental class and control class can be seen from the inferential statistical test conducted by the Independent t-test analysis. Before conducting independent $t$ test analysis, first carry out the homogeneity and normality tests in two sample groups as a prerequisite for conducting $t$ test analysis. The prerequisite test results show the two sample groups are normally distributed and homogeneous (sig.> 0.05). While the results of hypothesis testing indicates there is a significant difference of critical thinking skills in the two sample groups. The significant comparison between experimental and control class is shown in Table 4 which is the result of the $t$ test analysis that has been carried out.

Table 4. Independent t-test results in critical thinking skill

\begin{tabular}{|l|c|c|l|l|l|}
\hline Tes & df & $\begin{array}{l}\text { Mean } \\
\text { Differ } \\
\text { ence }\end{array}$ & $\begin{array}{l}\text { Std. } \\
\text { Error } \\
\text { Differ } \\
\text { ence }\end{array}$ & $\begin{array}{l}\text { Score t- } \\
\text { test }\end{array}$ & Sig. \\
\hline $\begin{array}{l}\text { Posttest } \\
\text { Eksperi } \\
\text { ment- } \\
\text { Control }\end{array}$ & 59 & 13.23 & 6.17 & -2.14 & 0.03 \\
\hline
\end{tabular}

Table 4 shows that the $t_{\text {count }}=2.14$ while the $t_{\text {table }}$ value for 59 degrees of freedom is 2.002 . The $t_{\text {count }}$ value in Table 4 is greater than the $t_{\text {table, }}$ 
indicates the use of smartphone-based learning media has a significant impact on students' critical thinking skills. This significant difference can be seen in Figure 1 which shows that all indicators of critical thinking skill in experimental class are better than the control class. The use of smartphone-based learning media that can display images, videos, and experimental animations that can train students' thinking skills [25] [26]. Critical thinking skill increases due to the use of smartphone-based learning media.

The comparison of students' critical thinking skills for each indicator is presented in Figure 1.

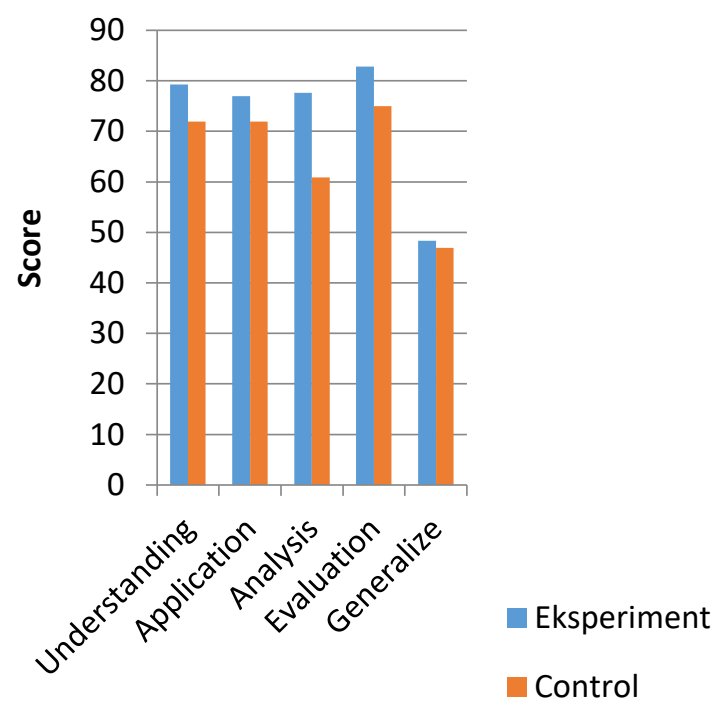

Indicator of Critical Thinking Skill

Figure 1 Comparison of Critical Thinking Skills for Each Indicator

Figure 1 shows all indicators of critical thinking skills can be trained using smartphonebased learning media. The understanding indicator in the experimental class got a score of 79.3, while the control class got a score of 71.9. Students who already understand something will find it easier to apply the material. This can be seen in the experimental class, the application indicator got a score of 77 while the control class only got a score of 71.9. The students'critical thinking skill is seen from the analysis and evaluation indicators in experimental class is higher than the control class. In experimental class that uses smartphone-based learning media, it is equipped with an experimental video animation which helps students to understand and analyze abstract subject matter [26]. The generalization indicator in experimental class was 48.3. It is higher than the control class which was only 46.9. This is because the smartphone-based learning media is equipped with completion steps to analyze and evaluate questions interactively. This evaluation step can train the thinking skills of students in making logical conclusions or decisions. By using smartphonebased learning media, students who can describe abstract subject matter to be more real and concrete.

\section{CONCLUSION}

This research result can be concluded that the use of smartphone-based learning media can affect the critical thinking skills during Covid-19 pandemic. Students' critical thinking skills in experimental class are better than the control class for each indicator namely understanding, application, analysing, evaluation, and generalize. Smartphone-based learning media which equipped images, videos, and experimental animations can help students understand abstract subject matter. It help students train their critical thinking skills.

\section{REFERENCES}

[1] E.M. Clarke, E.A. Emerson, Design and synthesis of synchronization skeletons using branching time temporal logic, in: D. Kozen (Eds.), Workshop on Logics of Programs, Lecture Notes in Computer Science, vol. 131, Springer, Berlin, Heidelberg, 1981, pp. 52-71. DOI: https://doi.org/10.1007/BFb0025774

[1] I.R. Lubis, J. Ikhsan, Pengembangan Media Pembelajaran Kimia Berbasis Android untuk Meningkatkan Motivasi Belajar dan Prestasi Kognitif Peserta Didik SMA, Jurnal Inovasi Pendidikan IPA 1(2) (2015) 191-201. DOI: https://doi.org/10.21831/jipi.v1i2.7504

[2] A. Khumaidi, I. Sucahyo, Pengembangan Mobile Pocket Book Fisika sebagai Media Pembelajaran Berbasis Android pada Materi Momentum dan Impuls, Jurnal Inovasi Pendidikan Fisika (JIPF) 7(2) (2018) 154-158. 
[3] Matsun, D.M. Ramdhani, I. Lestari, Perancangan Media Pembelajaran Listrk Magnet Berbasis Android di Program Studi, Jurnal Pendidikan Informatika dan Sains 7(1) (2018) 107-117. DOI:

https://doi.org/http://dx.doi.org/10.31571/saintek . $\mathrm{v} 7 \mathrm{i} 1.774$

[4] A.H. Ngurahrai, S.D. Farmayanti, N. Nurhidayati, Media Pembelajaran Materi Momentum dan Impuls Berbasis Mobile Learning untuk Meningkatkan Kemampuan Berpikir Kritis Siswa, Berkala Ilmiah Pendidikan Fisika 7(1) (2019) 62-70. DOI: https://doi.org/10.20527/bipf.v7i1.5440

[5] A.M. Zaus, R.E. Wulansari, S. Islami, D. Pernanda, Perancangan Media Pembelajaran Listrik Statis dan Dinamis Berbasis Android, Journal of Information Technology and Computer Science 1(1) (2018) 1-7. DOI: https://doi.org/https://doi.org/10.31539/intecoms .v1i1.167

[6] N. Wulandari, Pengembangan Media Pembelajaram Fisika Berbasis Andoid di SMA N 3 Ngabang, Jurnal Pendidikan Informatika dan Sains 9(1) (2020) 21-27. DOI: https://doi.org/10.31571/saintek.v9i1.1296

[7] L.D. Herliandry, N. Nurhasanah, M.E. Suban and H. Kuswanto, Pembelajaran Pada Covid 19, Jurnal Teknologi Pendidikan 22(1) (2020) 6570.

DOI:

https://doi.org/10.21009/jtp.v22i1.15286

[8] A.H. Yatmi, W. Wulandari, S. Ayub, Pengaruh Model Pembelajaran Generatif terhadap Kemampuan Berpikir Kritis Fisika Ditinjau dari Pengetahuan Awal Peserta Didik, Jurnal Pendidikan Fisika dan Teknologi 5(2) (2019), 287.

DOI:

https://doi.org/10.29303/jpft.v5i2.1327

[9] S.Y.E. Asmawati, U. Rosidin, Abdurahman, Efektivitas Instrumen Asesmen Model Creative Problem Solving pada Pembelajaran Fisika terhadap Kemampuan Berpikir Kritis Siswa, Jurnal Pendidikan Fisika Universitas Muhamadiyah Metro 6(2) (2018) 130. DOI: https://doi.org/http://dx.doi.org/10.24127/jpf.v6i $\underline{2.1318}$

[10] H. Rosidianto, E. Murdani, Penerapan Model Pembelajaran Group Investigation (GI) untuk Meningkatkan Keterampilan Berpikir Kritis Siswa pada Materi Gerak Lurus Kelas X, Jurnal
Ilmu Pendidikan Fisika 1(2) (2016) 49-51. DOI: https://doi.org/http://dx.doi.org/10.26737/jipf.v1 i2.63

[11] M. Firdaus, I. Wilujeng, Developing Students Worksheet on Guided Inquiry to Improve Critical Thinking Skills and Learning Outcomes of Students, Jurnal Inovasi Pendidikan IPA 4(1) 26-40.

DOI: http://dx.doi.org/10.21831/jipi.v4i1.5574

[12] N.W. Barra, I. Wilujeng, H. Kuswanto, The effect of inductive learning model assisted mindmap mindjet mindmanager towards critical thinking skills of students, in: Journal of Physics: Conference Series, vol. 1233, IOP Publishing, Bristol, 2019. DOI: https://doi.org/10.1088/17426596/1233/1/01204 $\underline{6}$

[13] S. Suriawati, Mundilarto, SETS Approach-Based Audiovisual Media for Improving The Students' Critical Thinking Skills, in: Psychology, Evaluation, and Technology in Educational Research 1(2) (2019) 95. DOI: https://doi.org/10.33292/petier.v1i2.15

[14] N.Y. Nafiah, N. Suyanto, Penerapan Model Problem-Based Learning untuk Meningkatkan Keterampilan Berpikir Kritis dan Hasil Belajar Siswa, Jurnal Pendidikan Vokasi 4(1) (2014) 125-143.

DOI: https://doi.org/10.21831/jpv.v4i1.2540

[15] W.J. Kusuma, Hamidah, Perbandingan Hasil Belajar Matematika dengan Penggunaan Platform Whatsapp Group dan Webinar Zoom dalam Pembelajaran Jarak Jauh pada Masa Pandemik Covid 19, Jurnal Ilmiah Pendidikan Matematikan 5(1) (2020) 97-106. DOI: https://doi.org/10.26877/jipmat.v5i1.5942

[16] A. Latip, Peran Literasi Teknologi Informasi dan Komunikasi pada Pembelajaran Jarak Jauh di Masa Pandemi Covid-19, EduTeach: Jurnal Edukasi dan Teknologi Pembelajaran 1(2) (2020) 108-116. DOI: https://doi.org/10.37859/eduteach.v1i2.1956

[17] B. Setiaji, C.A.P. Dinata, Analisis Kesiapan Mahasiswa Jurusan Pendidikan Fisika Menggunakan E-Learning dalam Situasi Pandemi Covid-19, Jurnal Inovasi Pendidikan IPA 6(1) (2020) 59-70. DOI: https://doi.org/10.21831/jipi.v6i1.31562 
[18] M.I. Suarsana, A.G. Mahayukti, Pengembangan E-Modul Berorientasi Pemecahan Masalah untuk Meningkatkan Keterampilan Berpikir Kritis Mahasiswa, Jurnal Nasional Pendidikan Teknik Informatika 2(3) (2013) 193. DOI: https://doi.org/10.23887/janapati.v2i3.9800

[19] S. Astuti, M. Danial, A. Muhammad, Pengembangan LKPD Berbasis PBL (Problem Based Learning) untuk Meningkatkan Keterampilan Berpikir Kritis Peserta Didik pada Materi Kesetimbangan Kimia, Chemistry Education Review (CER) 1(2) (2018) 90-114. DOI:

https://doi.org/https://doi.org/10.26858/cer.v0i1. $\underline{5614}$

[20] S. Husein, L. Herawati, Gunawan, Pengaruh Penggunaan Multimedia Interaktif terhadap Penguasaan Konsep dan Keterampilan Berpikir Kritis Siswa pada Materi Suhu dan Kalor, Jurnal Pendidikan Fisika dan Teknologi 1(3) (2015) 221-225.

DOI: https://doi.org/10.29303/jpft.v1i3.262

[21] Sabrina, H. Kuswanto, Android-Assisted Mobile Physics Learning through Indonesian Batik Culture: Improving Students' Creative Thinking and Problem Solving, International Journal of Instruction 11(4) (2018) 287-302. DOI: https://doi.org/10.12973/iji.2018.11419a

[22] H. Pratama, I. Prastyaningrum, Pengaruh Model Pembelajaran Project Based Learning Berbantuan Media Pembelajaran Pembangkit Listrik Tenaga Mikrohidro, Jurnal Penelitian Fisika dan Aplikasinya 6(2) (2016) 44-50. DOI: https://doi.org/http://dx.doi.org/10.26740/jpfa.v6 n2.p44-50

[23] Sugiyono, Educational Research Methods, Alfabeta, 2016.

[24] D. Sulisworo, Tingkat Kemampuan Berpikir Kritis Peserta Didik setelah Penerapan Model Pembelajaran Student Team Achievement Divisions (STAD) pada Siswa, in: Prosiding Seminar Nasional Quantum 2016, Universitas Negeri Ahmad Dahlan, Yogyakarta, 2016, pp. 175-182.

[25] S. Chodijah, A. Fauzi, R. Wulan, Pengembangan Perangkat Pembelajaran Fisika Menggunakan Model Guided Inquiry yang Dilengkapi Penilaian Portofolio pada Materi Gerak Melingkar, Jurnal Penelitian Pembelajaran Fisika 1 (2012) 1-19. DOI: https://doi.org/https://doi.org/10.1234/jppf.v1i1. $\underline{603}$

[26] S.F. Arista, H. Kuswanto, Virtual Physics Laboratory Application Based on The Android Smartphone to Improve Learning Independence and Conceptual Understanding, International Journal of Instruction 11(1) (2018) 1-16. DOI: https://doi.org/10.12973/iji.2018.1111a 